\title{
Nuclear Receptor-Interacting Protein 3
}

National Cancer Institute

\section{Source}

National Cancer Institute. Nuclear Receptor-Interacting Protein 3. NCI Thesaurus. Code C126616.

Nuclear receptor-interacting protein 3 (241 aa, $\sim 27 \mathrm{kDa}$ ) is encoded by the human NRIP3 gene. This protein may play a role in nuclear receptor activity or proteolysis. 